\title{
Cyathostomin fecal egg count and milk quality in dairy donkeys
}

\section{Contagem de ovos de Cyathostominae nas fezes e a qualidade do leite em jumentas lactantes}

\author{
Stefania Perrucci* (1D; Federica Salari'; Michela Maestrini ${ }^{1}$; Iolanda Altomonte ${ }^{1}$; Lisa Guardone ${ }^{1}$; \\ Simona Nardoni'; Marcelo Beltrão Molento2; Mina Martini \\ ${ }^{1}$ Department of Veterinary Sciences, University of Pisa, Pisa, Italy \\ ${ }^{2}$ Laboratório de Parasitologia Clínica Veterinária, Departamento de Medicina Veterinária, Universidade Federal do Paraná - UFPR, \\ Curitiba, PR, Brasil
}

How to cite: Perrucci S, Salari, Maestrini M, Altomonte I, Guardone L, Nardoni S, et al. Cyathostomin fecal egg count and milk quality in dairy donkeys. Braz J Vet Parasitol 2021; 30(2): e028220. https://doi.org/10.1590/S1984-29612021046

\begin{abstract}
This study was performed to assess the possible relationship between gastrointestinal strongylid infections and milk quantity and quality in donkeys used for milk production. Individual fecal and milk samples were collected from 16 multiparous lactating jennies of Amiatina breed at their $6^{\text {th }}$ month of lactation. Statistical analysis was carried out between strongylid eggs per gram of faeces (EPG) and milk parameters. All animals were found to shed cyathostomin eggs, with EPG ranging from 150 to 1900. A higher milk production was observed in animals showing an EPG $<250$, but this result was statistically not significant. Conversely, significant higher concentrations of milk urea and pH values, and lower concentrations of milk lactose, were observed in jennies with an EPG $>1000$. In conclusion, results from this study suggest that cyathostomin EPG values $>1000$ may affect milk quality in dairy donkeys. Considering the novelty of these findings, more data needs to be collected to determine EPG thresholds to be used as a good marker for parasite infections influencing milk performance and quality in donkeys.
\end{abstract}

Keywords: Dairy donkeys, milk quality, Cyathostominae, fecal egg count.

\section{Resumo}

Este estudo foi realizado com o objetivo de determinar a possível relação entre a infecção por estrongilídeos gastrintestinais e a quantidade e qualidade do leite de jumentas em lactação. Amostras individuais de fezes e leite foram coletados em 16 jumentas multíparas e lactantes da raça Amiatina no seu sexto mês de lactação. A análise estatística foi realizada entre a contagem de ovos de Cyathostominae por grama de fezes (OPG) e parâmetros do leite. Todos os animais estavam eliminando Cyathostominae nos ovos das fezes amostradas, variando entre 150 a 1.900 OPG. Embora não estatisticamente significativo, houve uma maior produção de leite em animais com OPG < 250. Inversamente, houve um aumento significativo na concentração de ureia e pH no leite, e baixa concentração de lactose foi observada nas jumentas com OPG > 1.000. Em conclusão, os resultados deste estudo sugerem que valores de OPG > 1.000 para ovos de Cyathostominae, podem comprometer a qualidade do leite em jumentas lactantes. Essa informação é original e mais dados necessitam ser obtidos para determinar os limites de OPG que poderão ser usados como marcadores para infecção parasitária, bem como na qualidade e "performance" de jumentas.

Palavras-chave: Jumentos para lactação, qualidade do leite, Cyathostominae parasitos, contagem de ovos nas fezes. 


\section{Introduction}

The interest in the breeding of dairy donkeys has increased in some European countries, particularly Italy. These animals are used for social activities, and their milk is used for the cosmetic industry and, mainly, for producing milk intended for human consumption (Camillo et al., 2018). Compared to that of other mammal species and based on its composition, donkey's milk is considered the closest to human breast milk (Altomonte et al., 2019). Donkey's milk is also well tolerated by children that are allergic to cow's milk proteins (Sarti et al., 2019), thus, it is now recognized as one of the best substitutes to cow's milk for human consumption (Polidori et al., 2015). Therefore, the control of diseases that can affect the quality, quantity, and safety of milk production is of the utmost importance in the dairy donkey farming.

Among the diseases of donkeys, endoparasites are frequently observed and may negatively affect the health and the productive performances of infected animals (Matthews \& Burden, 2013; Laus et al., 2015). Gastrointestinal nematodes are included among the most frequent endoparasite infections of donkeys worldwide (Matthews \& Burden, 2013; Ragona et al., 2016). Previous studies observed that milk production and composition may be reduced in small ruminants (Mavrot et al., 2015; Kyriánová et al., 2017) and cattle (Perri et al., 2011) infected with gastrointestinal strongyles. Nevertheless, studies on the possible impact of endoparasite infections on milk yield and quality in dairy donkeys are very scarce (i.e. Toxoplasma gondii) (Martini et al., 2014). This study aimed to correlate the quantitative and qualitative parameters of milk and the gastrointestinal strongylid infections measured by parasite fecal egg count in dairy donkeys.

\section{Material and Methods}

\section{Animals}

Sixteen lactating jennies of Amiatina breed were selected. The animals were reared outdoor in a semi-intensive dairy donkey farm located in Grosseto, Tuscany region, Italy. The farm rears about 200 donkeys and produces pasteurized milk for human consumption according to E.U. regulation 853/2004. The jennies did not have access to the pasture and were fed with poliphyte hay ad libitum and about $2.5 \mathrm{~kg}$ of concentrate/day/donkey, with an average total daily intake of about $8 \mathrm{~kg}$ of dry matter. During the first month of lactation, milk was completely devoted to the foals. Starting from one month after the delivery, the jennies were routinely machine milked. Jennies were separated from the foals four hours before milking.

With the aim of avoiding any differences possible deriving from the different stage of lactation and environmental factors, such as climate and season, all selected animals were multiparous and were at the sixth month of lactation of their third or fourth lactation (average age 8.33 \pm 1.80 ). All animals had delivered in the previous spring. Moreover, all examined jennies had an average body weight of $300 \mathrm{~kg}$ and a body condition score (BCS) of 3.5 (Burden, 2012). Their nutritional status was in the normal range based on the BCS and after a clinical evaluation. All jennies did not receive any anthelmintic treatment in the 12 months prior to the start of this study.

\section{Ethical declaration}

The study was carried out following the recommendations of the European Council Directive 155 (86/609/EEC) on the protection of animals and in adherence to a high standard of veterinary care. Ethical approval was not required in this study, as fecal sampling was performed by the veterinarian of the farm as part of the routine clinical visit and parasitological monitoring.

\section{Sampling}

From all the selected jennies, individual fecal and milk samples were taken once on the same day of lactation. More specifically, individual fecal samples were collected from the rectal ampoule, while milk samples (about $100 \mathrm{ml} /$ donkey) were collected from each jenny during machine milking. On the sampling day, the amount of milk obtained during morning machine-milking was recorded. All milk samples were used for a qualitative milk analysis. All fecal and milk samples were refrigerated at $4{ }^{\circ} \mathrm{C}$ immediately after the collection, transported to the laboratories and processed within 12 to $24 \mathrm{~h}$. 


\section{Milk quanti-qualitative analysis}

Milk parameters, as dry matter, fat, proteins, casein, lactose and urea content were evaluated on raw fresh milk samples by infrared analysis (MilkoScan 7 RM; Italian Foss Electric, Padova, Italy). The following analyses were also carried out: ash, $\mathrm{Ca}, \mathrm{P}, \mathrm{K}, \mathrm{Na}, \mathrm{Mg}, \mathrm{Zn}$, and pH. In brief, ash was quantified by incineration after drying (AOAC, 2006 method 945.46), while Ca, K, Na, Mg, and Zn were analysed by flame atomic absorption spectroscopy (AOAC, 2006 method 968.08), after digestion of the samples using nitric acid (HNO3; 65\%, Sigma-Aldrich) and perchloric acid (HClO4; 70\%, Sigma-Aldrich). P was quantified by spectrophotometric determination (AOAC, 2006 method 969.31). Milk pH was evaluated by using the potentiometric method.

\section{Parasitological methods}

For the search of gastrointestinal strongylids, individual fecal samples were quali- and quantitatively examined by a simple flotation test ( $\mathrm{NaCl}$ flotation solution with a specific gravity of 1.2), using a McMaster method with a sensitivity of 50 eggs per gram (EPG) of feces (Traversa et al., 2010). For the identification of the third stage larvae (L3) of gastrointestinal strongylids, pooled fecal cultures were performed with positive fecal samples. The cultures were placed in an incubator at $27^{\circ} \mathrm{C}$ for seven days and the L3 were recovered by the Baermann technique (Traversa et al., 2010). Larvae (about 100 larvae/pool) were microscopically examined and identified using morphological keys (Bevilaqua et al., 1993).

\section{Statistical analysis}

Statistical analysis was performed using the JMP 7.0 software (SAS Institute Inc., 2007, SAS, Cary, North Carolina, USA). Results regarding milk composition observed in donkeys showing different gastrointestinal strongylid EPG counts were analyzed using a one-way analysis of variance - ANOVA. To this aim, animals were allocated in different classes based on EPG counts. All the data were normally distributed. Considering that no differentiation of donkey's infection by gastrointestinal strongylids based on EPG count was available in the literature, we used data previously reported in horses (Ambrosi, 1995; Euzeby, 1981). Therefore, examined donkeys were allocated into the following three EPG classes: 1) < 250, low infection; 2) between 250 and 1000, mild infection; 3) > 1000, high infection.

The statistical model was the following:

$y i=\mu+\alpha i+\varepsilon i$

where: $y i$ is the dependent variable, $\mu$ is the overall mean, ai is the fixed effect of the $i^{\text {th }}$ EPG class $(i: 1, \ldots 3)$ and $\varepsilon i$ is the random error.

The significance level was set at $P<0.05$.

\section{Results}

All jennies (100\%) were shedding strongylid eggs with an EPG count ranging from 150 to 1900 (mean \pm standard error of the mean $850 \pm 159.9$ ). Coprocultures revealed that infections were mainly caused by cyathostomins $(100 \%)$ belonging to the genera Cylicocyclus and Cylicostephanus.

Jennies from the low infection group (<250 EPG) had an average milk production that was approximately $200 \mathrm{ml}$ higher when compared to animals from the high infection group (>1000 EPG). However, no significant variations in milk production were found among the three different EPG count-based groups of donkeys (Table 1). Conversely, in the three EPG-based groups of jennies, differences in milk quality were highlighted at statistical analysis. In fact, milk urea, lactose and $\mathrm{pH}$ were found to be significantly different. More specifically, significantly higher values of milk urea $(P<0.05)$ and $\mathrm{pH}(P<0.01)$, and significant lower values of milk lactose $(P<0.01)$ were observed in jennies with EPG $>1000$ (Table 1).

\section{Discussion}

In accordance with previous observations, all examined jennies in this study were found infected by gastrointestinal strongylids, represented only by cyathostomin species (100\%). Gastrointestinal nematode infections 
Table 1. Milk composition from 16 dairy donkey jennies at the sixth month of lactation and showing different levels of cyathostomin egg count (EPG).

\begin{tabular}{|c|c|c|c|c|c|}
\hline \multirow{2}{*}{$\begin{array}{l}\text { Milk parameters } \\
\text { (Least Square Mean } \\
\pm \text { Standard Error) }\end{array}$} & \multicolumn{3}{|c|}{ EPG 1} & \multirow{2}{*}{ RMSE $^{2}$} & \multirow{2}{*}{$P$ value } \\
\hline & $>1000$ & 250 to 1000 & $<250$ & & \\
\hline Quantity (ml) & $658.61 \pm 81.86$ & $622.33 \pm 115.76$ & $818.10 \pm 133.63$ & 191.56 & NS \\
\hline Fat (\%) & $0.65 \pm 0.12$ & $0.66 \pm 0.15$ & $0.76 \pm 0.18$ & 0.44 & NS \\
\hline Protein (\%) & $1.82 \pm 0.05$ & $1.85 \pm 0.06$ & $1.81 \pm 0.07$ & 0.26 & NS \\
\hline Casein (\%) & $0.71 \pm 0.03$ & $0.57 \pm 0.04$ & $0.83 \pm 0.04$ & 0.08 & NS \\
\hline Lactose (\%) & $6.82^{\mathrm{B}} \pm 0.02$ & $6.97^{A} \pm 0.03$ & $6.96^{A} \pm 0.04$ & 0.07 & $\star *$ \\
\hline Urea (mg/ml) & $41.32^{\mathrm{a}} \pm 1.96$ & $36.78^{\mathrm{ab}} \pm 2.60$ & $30.69^{b} \pm 3.00$ & 3.84 & * \\
\hline Dry Matter (\%) & $10.80 \pm 0.15$ & $10.39 \pm 0.19$ & $10.73 \pm 0.22$ & 1.25 & NS \\
\hline Ash (\%) & $0.40 \pm 0.02$ & $0.39 \pm 0.03$ & $0.39 \pm 0.03$ & 0.04 & NS \\
\hline $\mathrm{pH}$ & $7.01^{A} \pm 0.03$ & $6.83^{\mathrm{B}} \pm 0.03$ & $6.92^{\mathrm{AB}} \pm 0.04$ & 0.11 & $\star *$ \\
\hline Titratable acidity (g/l) & $0.13 \pm 0.007$ & $0.12 \pm 0.008$ & $0.12 \pm 0.008$ & 0.01 & NS \\
\hline $\operatorname{SCC}^{3}\left(n^{\circ} * 1000\right)$ & $5.52 \pm 0.93$ & $4.17 \pm 1.15$ & $4.67 \pm 1.49$ & 2.95 & NS \\
\hline $\mathrm{Ca}(\mathrm{mg} / \mathrm{L})$ & $967.53 \pm 296.22$ & $1233.69 \pm 323.42$ & $1242.56 \pm 315.41$ & 364.76 & NS \\
\hline $\mathrm{Mg}(\mathrm{mg} / \mathrm{L})$ & $106.85 \pm 9.87$ & $96.15 \pm 15.61$ & $89.82 \pm 12.17$ & 22.30 & NS \\
\hline $\mathrm{K}(\mathrm{mg} / \mathrm{L})$ & $714.20 \pm 38.53$ & $659.35 \pm 38.53$ & $631.20 \pm 49.74$ & 112.78 & NS \\
\hline $\mathrm{P}(\mathrm{mg} / \mathrm{L})$ & $468.00 \pm 43.46$ & $463.12 \pm 43.46$ & $435.85 \pm 56.11$ & 128.57 & NS \\
\hline $\mathrm{Na}(\mathrm{mg} / \mathrm{L})$ & $232.32 \pm 164.95$ & $338.96 \pm 164.95$ & $341.18 \pm 202.03$ & 188.53 & NS \\
\hline Zn (mg/L) & $1.52 \pm 0.24$ & $2.06 \pm 0.24$ & $2.16 \pm 0.31$ & 0.85 & NS \\
\hline
\end{tabular}

$1=$ Number of Eggs per gram (EPG) of feces; ${ }^{2}=$ Root mean square error (RMSE); ${ }^{3}=$ Somatic cell count (SCC). NS = no significant difference, ** $P<0.01, * P<0.05, A, B=$ Values within a row with different superscripts differ significantly at $P<0.01,{ }^{a}, \mathrm{~b}=$ Values within a row with different superscripts differ significantly at $P<0.05$.

are highly prevalent in donkeys, and prevalence ranging from 72 to $100 \%$ have been previously reported in Europe (Matthews \& Burden, 2013; Ragona et al., 2016). A higher prevalence of cyathostomin (small strongyles) compared to large strongyle infections were found in European donkey farms (Matthews \& Burden, 2013; Gokbulut et al., 2016). Although most of cyathostomin infected donkeys appear to remain clinically healthy even when high levels of infection occur unless they are nutritionally compromised or overworked (Gokbulut et al., 2014; Matthews \& Burden, 2013), the impact of cyathostomin infections on donkeys remains still to be defined (Matthee et al., 2002; Matthews \& Burden, 2013). Indeed, negative effects on body condition score and anemia have been reported in some studies (Matthee et al., 2002), while in other studies no correlation between cyathostomin egg count and body condition score was observed (Burden et al., 2010). In horses, a marked variability in individual susceptibility to cyathostomin infection has been observed in animals of the same farm, reflecting in different EPG counts (Clark et al., 2018). In adult horses, heritable components are included among the factors considered responsible for this inter-species variation, along with differences in immune response and gut microbiota, which may also play an important role (Clark et al., 2018). Similar differences in individual susceptibility to cyathostomin infection among donkeys may explain the variability of cyathostomin EPG observed in jennies examined in the present study, especially considering that all of them were adult multiparous animals of the same breed, at the same month of lactation, and similarly managed.

Previous studies in donkeys have evidenced that quantitative and qualitative milk parameters may be influenced by the health of the animal and of the udder, by the breed, and by the number and stage of lactation (Salari et al., 2019; Coroian et al., 2016). Environmental factors, such as climate and season, may also impact on the offer of good quality pasture with higher protein levels (Salari et al., 2020; Marchiș et al., 2018; Martini et al., $2015 ; 2018)$. Nevertheless, none of these factors varied among jennies examined in this study. In fact, all animals 
were apparently healthy after clinical examination and no signs of mastitis were observed. Moreover, all of them received the same feed.

Therefore, the results obtained in this study suggest that EPG values of gastrointestinal cyathostomin eggs higher than 1000 EPG may be a suitable marker of infection levels possibly responsible for quantitative and qualitative milk reductions in clinically asymptomatic dairy jennies, compared to animals with lower EPG counts. These findings agree with some previous data reported in ruminants infected with gastrointestinal strongyles (Rinaldi et al., 2007; Mavrot et al., 2015; Kyriánová et al., 2017), indicating that a high burden of gastrointestinal strongylid infections is likely to be an important factor in reducing milk yield and quality parameters, as the lactose and urea content. In equids, gastrointestinal strongylid infections may reduce nutrient availability through a reduction in voluntary feed intake and, especially cyathostomins, may cause protein-losing enteropathies due to increased intestinal permeability (Murphy \& Love, 1997; Escala et al., 2006). Although no data are available in dairy donkeys, in dairy cows it has been observed an increase in renal reabsorption of urea during periods of protein deficiency, with a consequent increase in milk urea nitrogen concentrations (Spek et al., 2013). Therefore, the reduction of protein availability and the modifications of protein metabolism, could explain the higher urea content observed in this study in the milk of jennies showing higher cyathostomin burdens. Moreover, the increase in milk pH may be a direct consequence of urea increase in milk.

\section{Conclusion}

The obtained results may be suggestive of the negative impact of high counts of cyathostomin eggs (EPG) over milk quality in dairy donkeys. However, further evaluations using a larger number of animals and involving other farms and management systems are needed to confirm these findings and to exclude other possible risk factors.

\section{Acknowledgements}

The authors wish to thank the University of Pisa for supporting this study under the University of Pisa Research Project, PRA 2017.

\section{References}

Altomonte I, Salari F, Licitra R, Martini M. Donkey and human milk: insights into their compositional similarities. Int Dairy J 2019; 89: 111-118. http://dx.doi.org/10.1016/j.idairyj.2018.09.005.

Ambrosi M. Parassitologia zootecnica. Bologna, Italy: Ed. Edagricole; 1995.

Association of Official Analytical Chemists - AOAC. Official methods of analysis, items 53 and 58. 17th ed. Gaithersburg, MD: AOAC; 2006.

Bevilaqua CML, Rodrigues ML, Concordet D. Identification of infective larvae of some common nematode strongylids of horses. Rev Med Vet 1993; 144: 989-995.

Burden FA, Du Toit N, Hernandez-Gil M, Prado-Ortiz O, Trawford AF. Selected health and management issues facing working donkeys presented for veterinary treatment in rural Mexico: some possible risk factors and potential intervention strategies. Trop Anim Health Prod 2010; 42(4): 597-605. http://dx.doi.org/10.1007/s11250-009-9462-0. PMid:19784862.

Burden F. Practical feeding and condition scoring for donkeys and mules. Equine Vet Educ 2012; 24(11): 589-596. http://dx.doi. org/10.1111/j.2042-3292.2011.00314.x.

Camillo F, Rota A, Biagini L, Tesi M, Fanelli D, Panzani D. The current situation and trend of donkey industry in Europe.J Equine Vet Sci 2018; 65: 44-49. http://dx.doi.org/10.1016/j.jevs.2017.11.008.

Clark A, Sallé G, Ballan V, Reigner F, Meynadier A, Cortet J, et al. Strongyle Infection and Gut Microbiota: Profiling of Resistant and Susceptible Horses Over a Grazing Season. Front Physio/ 2018; 9: 272. http://dx.doi.org/10.3389/fphys.2018.00272. PMid:29618989.

Coroian A, Miresan V, Odagiu A, Andronie L, Raducu C, Marchis Z, et al. Influence of Season on Physico-Chemical Composition of Donkey Milk from Primiparous and Multiparous. Pro Environ 2016; 9(28): 400-403.

Escala J, Gatherer ME, Voûte L, Love S. Application of the ${ }^{51} \mathrm{Cr}$-EDTA urinary recovery test for assessment of intestinal permeability in the horse. Res Vet Sci 2006; 80(2): 181-185. http://dx.doi.org/10.1016/j.rvsc.2005.07.004. PMid:16143355.

Euzeby J. Diagnostic Experimental des Helminthoses animals Livre 1. Travaux Pratiques d'Helminthologie Veterinaire. Paris, France: Informations Techniques des Services Vétérinaires; 1981. 
Gokbulut C, Aksit D, Santoro M, Roncoroni C, Mariani U, Buono F, et al. Plasma disposition, milk excretion and parasitological efficacy of mebendazole in donkeys naturally infected by Cyathostominae. Vet Parasitol 2016; 217: 95-100. http://dx.doi. org/10.1016/j.vetpar.2015.12.031. PMid:26827868.

Gokbulut C, Aksit D, Smaldone G, Mariani U, Veneziano V. Plasma pharmacokinetics, faecal excretion and efficacy of pyrantel pamoate paste and granule formulations following per os administration in donkeys naturally infected with intestinal strongylidae. Vet Parasitol 2014; 205(1-2): 186-192. http://dx.doi.org/10.1016/j.vetpar.2014.06.026. PMid:25015542.

Kyriánová IA, Vadlejch J, Kopecký O, Langrová I. Seasonal dynamics of endoparasitic infections at an organic goat farm and the impact of detected infections on milk production. Parasitol Res 2017; 116(11): 3211-3219. http://dx.doi.org/10.1007/s00436-0175643-3. PMid:29018987.

Laus F, Spaterna A, Faillace V, Veronesi F, Ravagnan S, Beribé F, et al. Clinical investigation on Theileria equi and Babesia caballi infections in Italian donkeys. BMC Vet Res 2015; 11(1): 100. http://dx.doi.org/10.1186/s12917-015-0411-z. PMid:25927984.

Marchiș Z, Odagiu A, Coroian A, Oroian I, Mîrza M, Burduhos P. Analysis of Environmental Factors' Impact on Donkeys' Colostrum Quality. Sustainability 2018; 10(9): 2958. http://dx.doi.org/10.3390/su10092958.

Murphy D, Love S. The pathogenic effects of experimental cyathostome infections in ponies. Vet Parasito/ 1997; 70(1-3): 99-110. http://dx.doi.org/10.1016/S0304-4017(96)01153-3. PMid:9195714.

Martini M, Altomonte I, Licitra R, Salari F. Short communication: technological and seasonal variations of vitamin D and other nutritional components in donkey milk. J Dairy Sci 2018; 101(10): 8721-8725. http://dx.doi.org/10.3168/jds.2018-14776. PMid:30055917.

Martini M, Altomonte I, Mancianti F, Nardoni S, Mugnaini L, Salari F. A preliminary study on the quality and safety of milk in donkeys positive for Toxop/asma gondii. Animal 2014; 8(12): 1996-1998. http://dx.doi.org/10.1017/S1751731114001980. PMid:25118707.

Martini M, Altomonte I, Manica E, Salari F. Changes in donkey milk lipids in relation to season and lactation.J Food Compos Anal 2015; 41: 30-34. http://dx.doi.org/10.1016/j.jfca.2014.12.019.

Matthee S, Krecek RC, Milne SA, Boshoff M, Guthrie AJ. Impact of management interventions on helminth levels, and body and blood measurements in working donkeys in South Africa. Vet Parasitol 2002; 107(1-2): 103-113. http://dx.doi.org/10.1016/S03044017(02)00113-9. PMid:12072218.

Matthews JB, Burden FA. Common helminth infections of donkeys and their control in temperate regions. Equine Vet Educ 2013; 25(9): 461-467. http://dx.doi.org/10.1111/eve.12018.

Mavrot F, Hertzberg H, Torgerson P. Effect of gastro-intestinal nematode infection on sheep performance: a systematic review and meta-analysis. Parasit Vectors 2015; 8(1): 557. http://dx.doi.org/10.1186/s13071-015-1164-z. PMid:26496893.

Perri AF, Mejía ME, Licoff N, Lazaro L, Miglierina M, Ornstein A, et al. Gastrointestinal parasites presence during the peripartum decreases total milk production in grazing dairy Holstein cows. Vet Parasito/ 2011; 178(3-4): 311-318. http://dx.doi.org/10.1016/j. vetpar.2010.12.045. PMid:21269774.

Polidori P, Ariani A, Vincenzetti S. Use of donkey milk in cases of cow's milk protein allergies. Int J Child Health Nutr 2015; 4(3): 174-179. http://dx.doi.org/10.6000/1929-4247.2015.04.03.6.

Ragona G, Corrias F, Benedetti M, Paladini M, Salari F, Altomonte I, et al. Amiata donkey milk chain: animal health evaluation and milk quality. Ital J Food Saf 2016; 5(3): 5951. http://dx.doi.org/10.4081/ijfs.2016.5951. PMid:27853717.

Rinaldi L, Veneziano V, Cringoli G. Dairy goat production and the importance of gastrointestinal strongyle parasitism. Trans $R$ Soc Trop Med Hyg 2007; 101(8): 745-746. http://dx.doi.org/10.1016/j.trstmh.2007.03.010. PMid:17433822.

Salari F, Ciampolini R, Mariti C, Millanta F, Altomonte I, Licitra R, et al. A multi-approach study of the performance of dairy donkey during lactation: preliminary results. Ital J Anim Sci 2019; 18(1): 1135-1141. http://dx.doi.org/10.1080/1828051X.2019.1623094.

Salari F, Licitra R, Altomonte I, Martini M. Donkey Feeding During Maintenance, Pregnancy, and Lactation: Effects on Body Weight, Milk Production, and Foal Growth.J Equine Vet Sci 2020; 91: 103131. http://dx.doi.org/10.1016/j.jevs.2020.103131. PMid:32684269.

SAS Institute Inc. Version 7.0. Cary, NC: SAS Institute Inc.; 2007.

Sarti L, Martini M, Brajon G, Barni S, Salari F, Altomonte I, et al. Donkey's milk in the management of children with cow's milk protein allergy: nutritional and hygienic aspects. Ital J Pediatr 2019; 45(1): 102. http://dx.doi.org/10.1186/s13052-019-0700-4. PMid:31420060.

Spek J, Dijkstra J, van Duinkerken G, Bannink A. A review of factors influencing milk urea concentration and its relationship with urinary urea excretion in lactating dairy cattle. J Agric Sci 2013; 151(3): 407-423. http://dx.doi.org/10.1017/S0021859612000561.

Traversa D, Milillo P, Barnes H, von Samson-Himmelstjerna G, Schurmann S, Demeler J, et al. Distribution and species-specific occurrence of cyathostomins (Nematoda, Strongylida) in naturally infected horses from Italy, United Kingdom and Germany. Vet Parasitol 2010; 168(1-2): 84-92. http://dx.doi.org/10.1016/j.vetpar.2009.10.006. PMid:19906489. 